\title{
Correction to: Community signals of the effect of Didymosphenia geminata (Lyngbye) M. Schmidt on benthic diatom communities in Chilean rivers
}

Jacqueline Salvo Pereira* and Alejandra Oyanedel Pérez

\section{Correction to: Rev Chil Hist Nat. 2019;92:4}

https://doi.org/10.1186/s40693-019-0084-2

The original article [1] contained a minor typo in the spelling of 'Lyngbye' in the title; this has now been corrected.

Published online: 08 August 2019

\section{Reference}

1. Salvo Pereira J, Oyanedel Pérez A. Community signals of the effect of

Didymosphenia geminata (Lyngbye) M. Schmidt on benthic diatom

communities in Chilean rivers. Rev Chil Hist Nat. 2019;92:4. https://doi.org/1

0.1186/s40693-019-0084-2.

* Correspondence: jacqueline.salvo@ifop.cl

Departamento de Medio Ambiente Instituto de Fomento Pesquero, Puerto, Montt, Chile 